\title{
Pensononowoor
}

2014, vol. 71, 109-117

http://dx.doi.org/10.12657/denbio.071.011

\author{
Emel Uslu, Yasin Bakış
}

\section{Morphometric analyses of the leaf variation within Quercus L. Sect. Cerris Loudon in Turkey}

Received: 25 February 2012; Accepted 29 July 2013

\begin{abstract}
Oaks are classified heavily based on the leaf morphology. However, identification of specimens without acorns is usually controversial in Cerris section. Although members of Cerris section have a broad distribution area, there are only few taxonomic studies. Therefore, the current study is the first to show the discrimination of species in Cerris section based on leaf characters from Turkey. Discrimination among the members of Cerris section over Turkey (Q. cerris L. var. cerris, Q. ithaburensis Decne. subsp. macrolepis (Kotschy) Hedge and Yalt, Q. brantii Lindley, Q. libani Olivier, and Q. trojana P. B. subsp. trojana.) was aimed and variations within and among the species based on 15 qualitative leaf characters was presented. In this work we have studied the natural variability of these species by analysing leaf materials collected from 44 populations around Turkey. Cluster Analysis (CA) and Principal Component Analysis (PCA) were performed to assess intra-specific differentiation and to compare the distribution of variance in the individual and population level. The results showed that the leaf characters presented a good discrimination of five Cerris taxa in PCA at the population level, but the relationships between Q. ithaburensis subsp. macrolepis and $Q$. brantii showed complex groups in CA. Among the studied taxa, the highest variation was found within Q. cerris populations. In this work, we obtained discrimination of Cerris section species from Turkey based on leaf characters which is quite useful for those herbarium specimens without acorns and in other systematic observations.
\end{abstract}

Additional key words: cluster analysis, numerical taxonomy, oak, principal component analysis

Address: Abant İzzet Baysal University, Faculty of Science and Art, Department of Biology, Gölköy 14280 Bolu, Turkey; e-mail: uslu_e@ibu.edu.tr

\section{Introduction}

The genus Quercus L. is one of the most abundant and economically-important genera of woody plants belonging to the Fagaceae family. It frequently exists as the dominant species in the Mediterranean area of the Northern Hemisphere (Manos et al. 2001; Govaerts and Frodin 1998). Quercus genus contains about 531 species in the last check list released by Gov- aerts and Frodin (1998) and is distributed across the Americas, Asia, Malaysia, Europe and North Africa. In Turkey, Quercus genus is represented with 23 taxa from three different Sections: Quercus, Ilex Loudon, and Cerris Loudon (Hedge and Yaltırık 1982; Yaltırık 1984). In the Flora of Turkey the Cerris section has five species including three infraspecific taxa, namely Q. cerris L. var. cerris, Q. cerris L. var. austriaca, (Willd) Loudon, Q. ithaburensis subsp. macrolepis, (Kotschy) 
Hedge and Yalt, Q. brantii Lindley, Q. libani Olivier, Q. trojana P. B. and Q. trojana subsp. yaltrrikii Ziel. et al. (Hedge and Yaltırık 1984; Zielinski et al. 2006).

Oaks are woody, long-lived and wind-pollinated species. Therefore, they can spread across wide geographic regions and so they show high levels of variation (Kremer and Petit 1993; Hokanson et al. 1993; Bacilieri et al. 1996). Since breeding barriers between Quercus species are extremely weak, oaks living in mixed populations show hybridization behaviour either in the same or in different sections (Bacilieri et al. 1996; Manos et al. 1999; Samuel 1999).

The taxonomy of genus Quercus is based on morphological traits mainly, which are crucial to differentiating species within the genus (Dupouey and Badeau 1993; Bruschi et al. 2000). Seed characters of oaks - seed size especially - shows high level of variation within the same species in some taxa (Anagiotos et al. 2012). Therefore, leaf characters are important in the classification of oaks (Stace 1989) and in the determination of the limits of species (Jensen et al. 1984). Leaf characters are used for classification of most oaks and they are also one of the most important indicators in identification of hybrid samples. Vegetative characters are used reluctantly in groups where reproductive characters are not helpful in classification (Stace 1989).

Due to hybridization problems in oaks, most of the species in Turkey and all distributed countries have taxonomic problems. Because of environmental variations, some of the Quercus taxa are mixed together and their delimitations are difficult to determine. To solve these problems, it is necessary to determine the boundaries of taxa (Borazan and Babaç 2003). Another important reason for the variation among oak species is varying environmental factors in different geographical regions (Petit et al. 1997). Morphological variations are usual within the same species living in different geographical regions and having distinct ecological factors. Discovering the reasons for variations is very important in Quercus taxonomy. Beside the other factors, variations may most probably be caused by ecological or genetic factors (Davis and Heywood 1963).

The distributions of $Q$. ithaburensis subsp. macrolepis and Q. brantii over Turkey are geographically separated by the Anatolian Diagonal (Davis 1971; Ekim and Güner 1986; Borazan and Babaç 2003; Uslu et al. 2011; Uslu and Bakış 2012). A similar geographical isolation mechanism was also reported between Q. trojana and Q. libani by Borazan and Babaç (2003) and Uslu and Bakıș (2012). Q. ithaburensis subsp. macrolepis and $Q$. brantii can be discriminated from each other according to their fruit characteristics and their geographical distribution. However, fruitless samples can be problem. Some nomenclature and typification problems still remain in $Q$. ithaburensis complexes
(Hedge and Yaltırık 1982). Morphometric analyses are generally used to demonstrate discrimination among the operational taxonomic units (OTUs). Therefore, we aimed to show discrimination among the members of Cerris section in Turkish Flora and to present variations within and among the species. Identification of $Q$. ithaburensis - Q. brantii, and $Q$. libani - Q. trojana, and some forms of $Q$. brantii - $Q$. libani based on leaves are usually confused when the herbarium specimens are missing acorns. In order to solve this problem, and achieve mentioned aims, morphometric leaf characters were analysed by the most frequently used multivariate statistics techniques: Cluster Analysis and Principal Component Analysis.

\section{Material and Methods}

Botanical Specimens: A total of 260 tree specimens (55 from Q. brantii, 55 from Q. cerris, 50 from Q. ithaburensis subsp. macrolepis, 52 from $Q$. libani, and 48 from $Q$. trojana subsp. trojana) were collected from 44 populations that are belong to Cerris section over Turkey (Appendix 1, Fig. 1) for the analyses. Populations were studied at the species level and infraspecific taxa were considered with belonging species. For each population, number of trees varied between ten and fifteen. For each tree, eight to ten leaves were randomly selected. To avoid seasonal and positional variations, samples were collected from different branches at approximately the same height and location where leaf growth had stopped (Blue and Jensen 1988).

For each character, mean values of each population were calculated. A total of fifteen morphometric characters were used as in previous studies of Jensen (1980; 1988; 1989), Stace (1989), Borazan and Babaç (2003) and Zúñiga et al. (2009). The morphological characters employed in this study and their explanations are presented in Figure 2.

This point forward, the taxa $Q$. ithaburensis subsp. macrolepis, $Q$. cerris var. cerris and $Q$. trojana subsp. trojana will be referred to as $Q$. ithaburensis and $Q$. cerris and $Q$. trojana, respectively.

Morphometric Analysis: For each character, data ranges of each taxon were tabulated in order to show their discriminative influence. Both cluster and principal component analysis techniques were used. Morphometric analyses were performed by Minitab version 16. A basic data matrix of 44 populations by 15 characters was created for this purpose. The data was standardized by using the linear transformation algorithm functions in Minitab program in order to reduce the effects of different measurement scales in different characters. To do this, the mean and the standard deviation of each character were used. 
We computed a dissimilarity matrix using Euclidean distance coefficients (Dunn and Everitt 1982; Abbot et al. 1985) for the Cluster Analysis. A dendrogram was therefore produced using the unweighted pair group arithmetic averages method (UPGMA). Principal Component Analysis was performed with standardized data using a correlation matrix (Abbot et al. 1985).

\section{Results}

In this study, samples from 44 populations over Turkey belonging to the Cerris section of Quercus were analysed with Cluster Analysis and Principal Component Analysis. Two data matrices, 15 characters by 44 OTUs and 15 characters by 260 OTUs were created based on populations and tree specimens respectively.

For the aim of discrimination of taxa for each single character representation, minimum and maximum average values have been tabulated in Table 1 . NPLB has been one of the best discriminative characters. It separated taxa into three distinct groups clearly: Q. libani; Q. trojana - Q. brantii; and Q. ithaburensis - Q. cerris. Another valuable character to discriminate the studied taxa, IBPS, resulted in three groups similarly: Q. brantii; $Q$. ithaburensis - Q. cerris; $Q$. libani - Q. trojana. Although many characters revealed that $Q$. cerris, $Q$. brantii and $Q$. ithaburensis have been grouped together, some characters such as ICWI and DBW have discriminated $Q$. cerris from $Q$. ithaburensis and $Q$. brantii clearly. On the other hand, in most cases $Q$. trojana has formed a complex with $Q$. libani. A few characters, LBW, LBL, and DBW, were able to discriminate these two taxa.

In the CA three main groups were obtained by a phenon line at a 5.08 dissimilarity level (Fig. 3). The phenon line was drawn according to variance decomposition for the optimal classification with reasonable values such as $43.96 \%$ within classes and $56.04 \%$ among classes. The first group was composed of the two clusters of $Q$. trojana and $Q$. libani. In the second group, CA was not able to form separate clusters for $Q$. brantii and $Q$. ithaburensis. Only $Q$. brantii populations from Adıyaman - Nemrut Mountain (BRN283 and BRN 284) and from Elazığ - Sivrice and Baskil (BRN287 and BRN286) were combined in the first subgroup. The second subgroup contained four different small groups in which three belong to $Q$. ithaburensis and one to the $Q$. brantii populations. One of these small groups covered the populations of conserved $Q$. ithaburensis old trees (ITH122, ITH130 and ITH198) which were located in the North Aegean coastal region. The second small group was composed of populations in which trees were sparsely distributed in cultivated areas. The third group was composed of populations of $Q$. cerris only (Fig. 3).
The dendrogram (Fig. 3) which produced as a result of CA was unable to group the $Q$. brantii and $Q$. ithaburensis populations separately. When we looked at the habitat information of samples, we have seen that, populations of sparsely distributed trees in cultivated areas were located separately from the populations of conserved small woodlands. Populations BRN283, BRN284, BRN286, and BRN287 are representatives of small forest habitats which had clustered separately from the remaining $Q$. brantii populations that are composed of sparsely distributed trees. This is more or less the same for the $Q$. ithaburensis populations. Furthermore, the main differences between $Q$. ithaburensis and $Q$. brantii are the size dependent characters in the dataset.

Two PCA plots, at population level and at individual (tree) level, are presented in figure 4 and figure 5 respectively. Components in the PCA plot of populations revealed $72 \%$ of total variation approximately and $65 \%$ in the PCA plot of tree specimens. PCA based on the populations' data gives a clear cut discrimination of all five Cerris taxa from the remaining taxa and Q. trojana and Q. libani could be discriminated using either one of the factors. On the other hand, one would need both first and second factors to discriminate the remaining taxa. $Q$. libani formed a dense distribution of samples while the remaining taxa - especially $Q$. cerris and $Q$. ithaburensis - were scattered loosely. Similar to the dendrogram produced by cluster analysis, Q. trojana and Q. libani were plotted closely on the left hand side of the plot, $Q$. cerris was at the opposite side and Q. ithaburensis and $Q$. brantii were located at the middle. However, the introgression between $Q$. ithaburensis and $Q$. brantii samples were resolved in PCA (Fig. 4).

The PCA based on tree samples (Fig. 5) was plotted to show the variations among the individual tree specimens. The central locations of each taxon were plotted and found to be similar to PCA plot of populations. However, the samples showed an introgressive distribution in Figure 5. It is not an easy task to perform a clear cut discrimination of taxa in this case. The most distinct taxa were $Q$. libani and $Q$. trojana, while the other three taxa showed overlapping distributions (Fig. 5).

\section{Discussion}

Comparison of taxa ranges within the characters (Table 1) had shown that most of them were separated at least into two groups. This indicated that chosen characters were also informative solely. The main subtraction from these comparisons would be the grouping of $Q$. brantii - Q. cerris - Q. ithaburensis complex and $Q$. libani $-Q$. trojana complex separately. Results of CA (Fig. 3) and PCA (Figs 4, 5) have also 

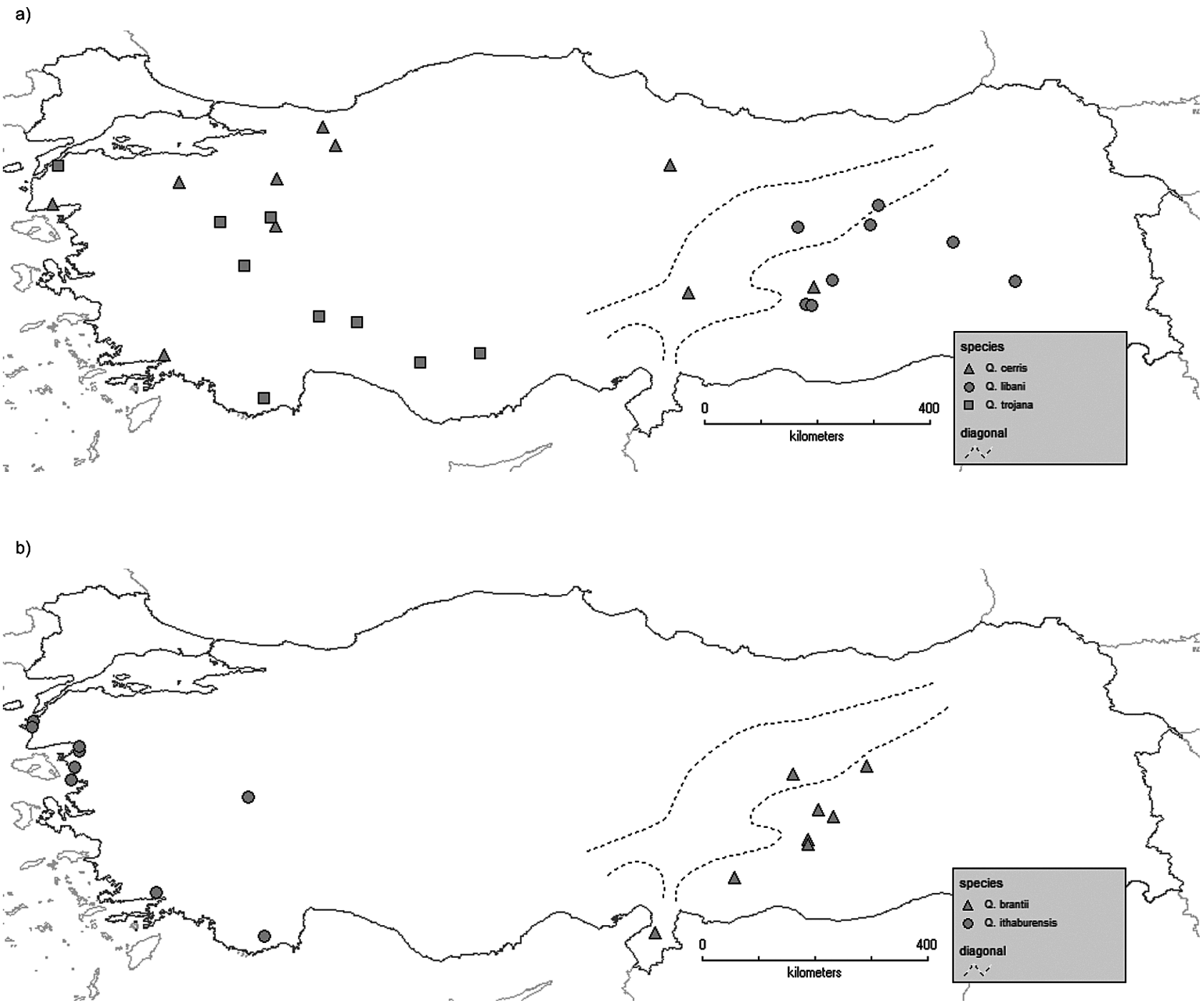

Fig. 1. Geographical distributions of Section Cerris populations belonging to a) Q. cerris, Q. libani, Q. trojana, b) Q. brantii, and Q. ithaburensis according to the Anatolian Diagonal (presented with dotted line)

supported these complexes. This was most probably caused by the size depending property of leaf characters, since most of the characters were based on measurements.

On the other hand, character NPLB gave a good discrimination with three groups: Q. libani; Q. troja$n a-Q$. brantii; Q. ithaburensis - Q. cerris. Contrarily, $Q$. libani and $Q$. trojana have been grouped closely according to size dependent characters. Therefore, using combination of characters would give the best discriminations among the taxa as seen in results of CA (Fig. 3) and PCA (Figs 4, 5).

In both the CA and PCA results, Q. trojana and Q. libani were grouped as separate clusters. This result was significant, since those two taxa were distinguished according to their fruits generally rather than their leaves (Hedge and Yaltırık 1982; Yaltırık 1984). Section members were clearly grouped within the PCA plots and clustered in the CA dendrogram, with exceptions of $Q$. brantii and $Q$. ithaburensis in the CA. In both graphs, $Q$. cerris were placed away from Q. trojana and Q. libani. This was most possibly caused by the primitive structure of leaf venation in $Q$. trojana and Q. libani but not in Q. cerris, as mentioned in Yaltırık (1984) and Kasapligil (1992). Leaf venations in primitive forms were pinnate type; where secondary veins paired opposite as in $Q$. trojana and $Q$. libani. The other venation types that are found in other taxa were called derived in this study. The two remaining taxa, $Q$. brantii and $Q$. ithaburensis, were placed in the middle since they are at the transition between primitive and derived forms. This feature also causes $Q$. libani and $Q$. trojana to form a dense distribution of samples while the remaining taxa, especially $Q$. cerris, were scattered loosely due to low variation rates in primitive leaves and high variation rates in more derived forms. 


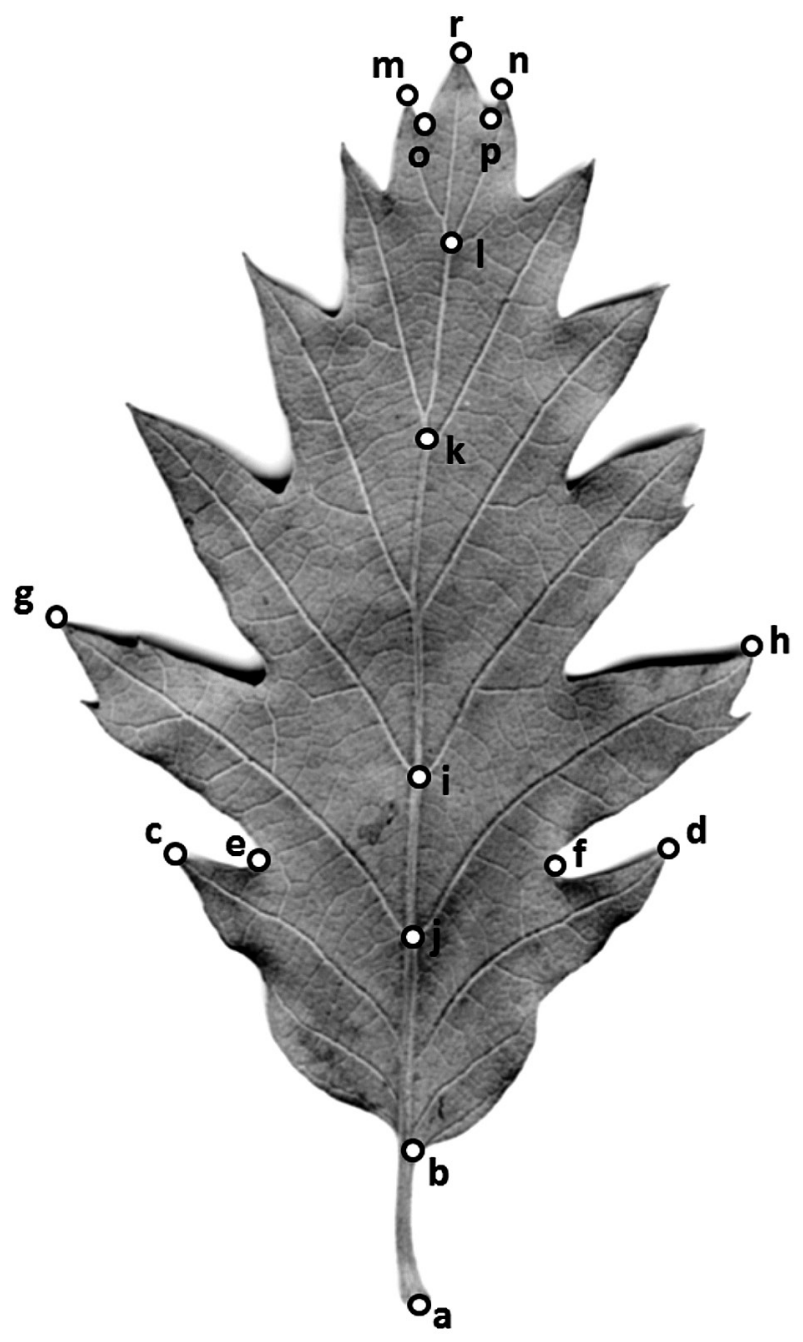

Fig. 2. Graphical representation of landmark points used for morphometric measurements and the list of morphological characters scored from leaves. NPLB: Total number of primary leaf lobes*; LBL: Leaf blade length (r-b); LBW: Leaf blade width (at the widest point) (gh); DBW: The distance between the widest point and the leaf base (i-b); BLW: Basal lobe pair width* (c-d); ALW: Apical lobe pair width* (m-n); DAB: The distance between the apical lobe pair and basal lobe pair at the right side of the leaves* (d-n); ICVI: Interval between approximately central vein intersections (i-j); IAVI: Interval between apical vein intersections (k-l); IBPS: Interval between basal pair of sinuses* (e-f); IAPS: Interval between apical pair of sinuses* $(\mathrm{o}-\mathrm{p})$; PTL: Petiole length (a-b); LBL/LBW: Leaf blade length / Leaf blade width; BLW / IBPS: Basal lobe pair width / Interval between basal pair of sinuses*; ALW / IAPS: Apical lobe pair width / Interval between apical pair of sinuses*. (* For the leaf types such as Q. libani and Q. trojana, the tooth measurements are scored instead of lobes)

On the other hand, hybridization is very common in the eastern part of the Anatolian Diagonal between $Q$. brantii and the taxa of Quercus section members, especially with $Q$. infectoria subsp. boissieri (Zohary 1973; Menitsky 2005; Yaltırık 1984; Kasaplıgil 1992). Some of these hybrids and their leaf characters are very similar to those of $Q$. ithaburensis (Yaltırık 1984; Kasapligil 1992). However, Q. brantii and Q. ithaburensis taxa were separated from one another in terms of geographical distribution. Although, samples of $Q$. ithaburensis populations appeared in the $Q$. brantii and $Q$. cerris groups in the CA results, they actually form a separate fifth group in PCA's (Figs. 4-5). Although the general thought that $Q$. brantii are distributed in

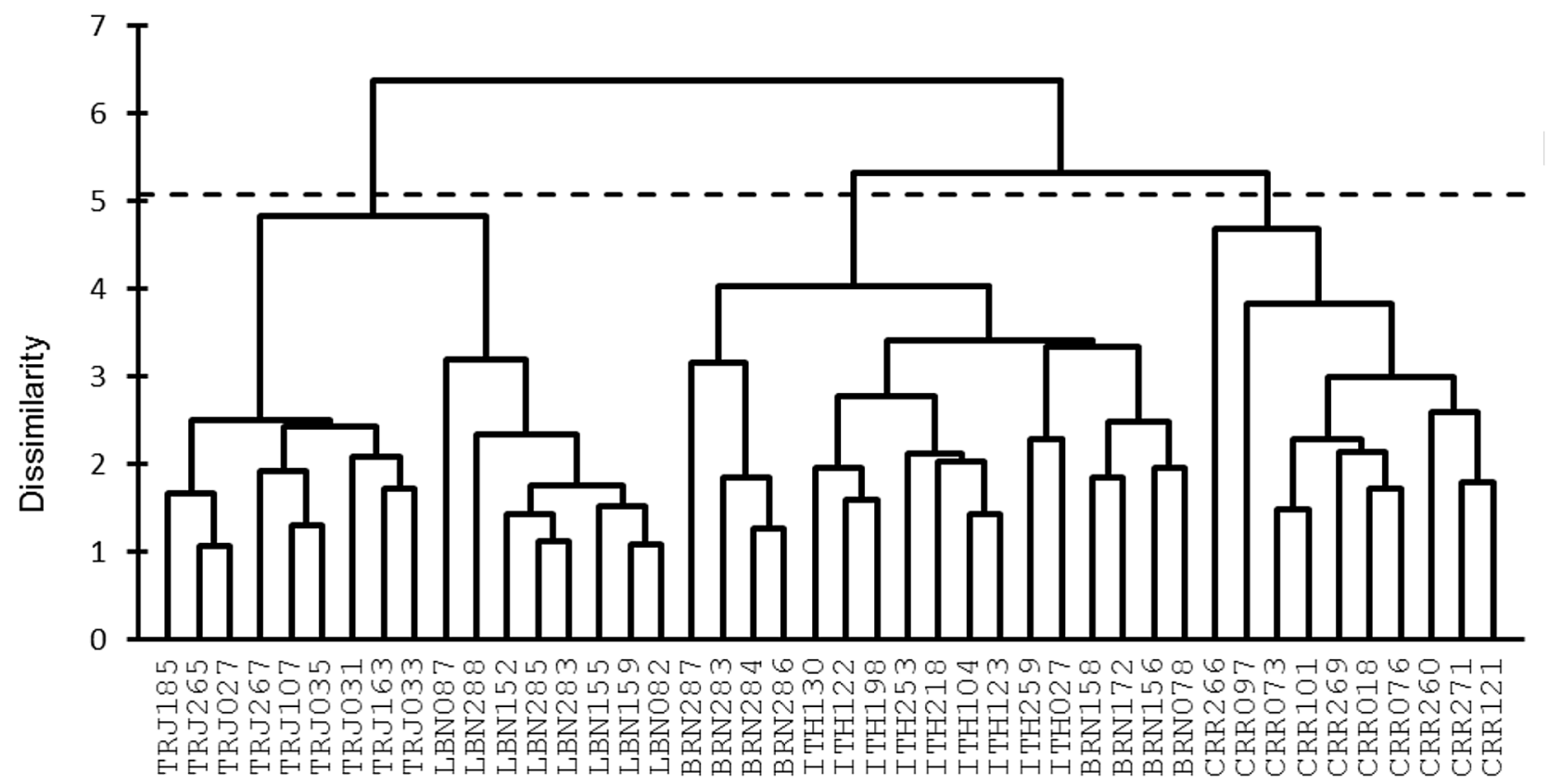

Fig. 3. Dendrogram of populations generated by Cluster Analysis using the UPGMA method 


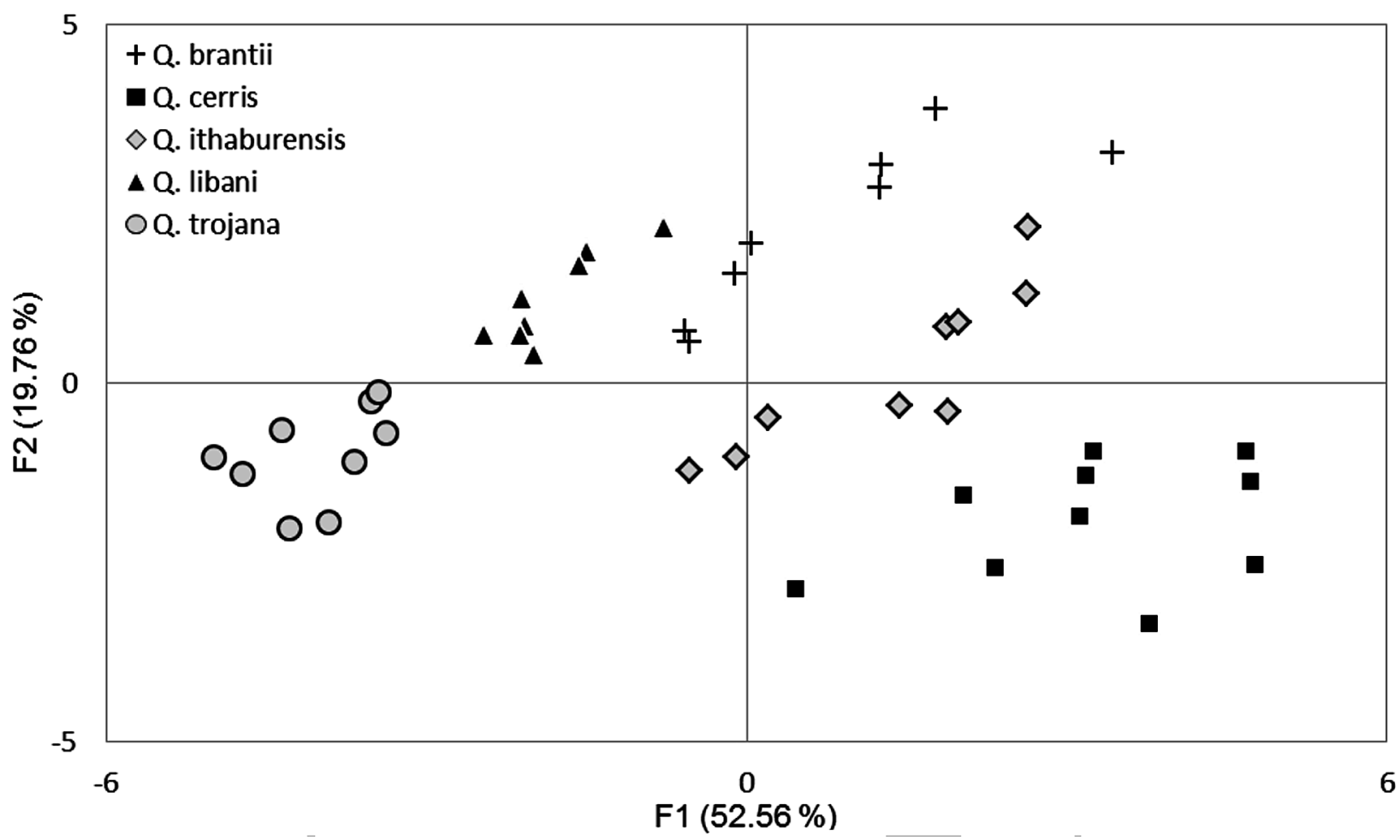

Fig. 4. Plot of distributions of populations generated by PCA, according to components 1 and 2

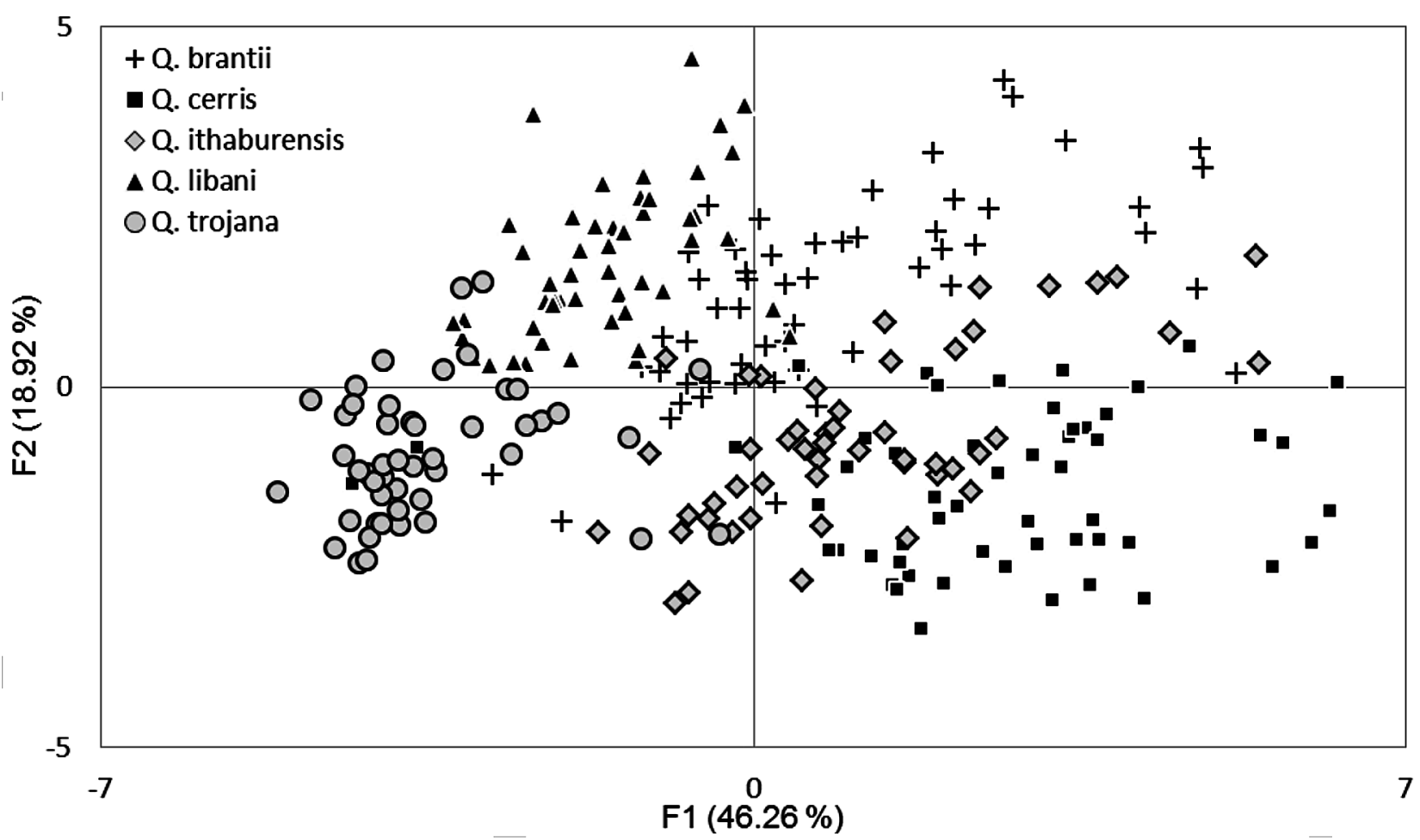

Fig. 5. Plot of distributions of tree specimens within populations generated by PCA, according to components 1 and 2 
Table 1. Comparison of minimum-maximum averages of leaf characters for the studied taxa

\begin{tabular}{lccccc}
\hline \multicolumn{1}{c}{ Characters*Taxa } & Q. brantii & $\begin{array}{c}\text { Q. cerris } \\
\text { var. cerris }\end{array}$ & $\begin{array}{c}\text { Q. ithaburensis } \\
\text { subsp. macrolepis }\end{array}$ & Q. libani & $\begin{array}{c}\text { Q. trojana subsp. } \\
\text { trojana }\end{array}$ \\
\hline NPLB & $16.56-22.18$ & $10.43-15.28$ & $12.83-15.60$ & $23.52-27.74$ & $18.70-24.12$ \\
LBL & $6.32-8.47$ & $7.05-9.31$ & $5.39-7.94$ & $7.87-9.12$ & $4.48-6.64$ \\
LBW & $3.07-5.24$ & $3.57-4.75$ & $2.92-4.64$ & $2.54-3.37$ & $1.77-2.44$ \\
DBW & $2.94-3.64$ & $3.65-5.29$ & $2.40-3.44$ & $2.88-3.78$ & $1.93-2.92$ \\
BLW & $3.06-4.56$ & $2.35-2.92$ & $2.56-3.68$ & $2.12-2.73$ & $1.47-2.01$ \\
ALW & $0.60-1.23$ & $0.82-1.64$ & $0.81-1.33$ & $0.43-0.53$ & $0.33-0.48$ \\
DAB & $4.86-7.28$ & $5.35-7.14$ & $3.68-6.82$ & $6.21-7.72$ & $3.89-5.36$ \\
ICVI & $0.63-1.06$ & $0.94-1.77$ & $0.84-1.30$ & $0.65-0.80$ & $0.45-0.89$ \\
IAVI & $0.65-1.17$ & $1.09-1.87$ & $0.78-1.32$ & $0.51-0.70$ & $0.45-0.67$ \\
IBPS & $2.68-4.03$ & $0.97-2.16$ & $1.99-3.20$ & $1.38-2.07$ & $1.14-1.84$ \\
IAPS & $0.33-0.96$ & $0.46-0.90$ & $0.49-0.83$ & $0.27-0.42$ & $0.21-0.48$ \\
PTL & $1.01-1.43$ & $0.57-1.25$ & $1.00-1.67$ & $0.97-1.52$ & $0.37-0.79$ \\
LBL/LBW & $1.47-2.13$ & $1.84-2.36$ & $1.68-2.11$ & $2.76-3.32$ & $2.59-3.31$ \\
BLW/IBPS & $1.06-1.31$ & $1.32-1.99$ & $1.13-1.42$ & $0.67-1.37$ & $0.80-1.15$ \\
ALW/IAPS & $1.16-1.86$ & $1.74-2.74$ & $1.33-1.80$ & $1.25-1.81$ & $1.08-1.78$
\end{tabular}

*See Fig. 2 for the character codes.

the west and Q. ithaburensis in the east of the Anatolian Diagonal, we do not observed such separation during our field trips. We believe that false identifications were caused by the herbarium specimens that are not having fruit parts.

Q. cerris, which is well-known for its irregular leaf shapes, has the highest level of variations on leaf characters in PCA (Fig. 5). Schwarz's classification of oaks in Anatolia supports this result (Schwartz 1993). Q. cerris is such a complex group and is one of the species in Section Cerris of Turkish Flora with infraspecific taxa. In addition, Q. cerris has a potential to hybridize with other taxa (Kasapligil 1992; Schwartz 1993; Conte et al. 2007; Bellarosa et al. 2005).

Current classification and identification of the section is mainly based on the leaf and fruit characters. Leaves are particularly significant as the availability of fruits depends on the seasons (Stace 1989; Jensen et al.1984). The biennial maturation of fruits as characteristic to Cerris section (Hedge and Yaltırık 1982) also makes studies based on fruit morphology difficult. In this study, we have conducted the most comprehensive morphometric analysis of leaves belong to the Turkish Cerris to date.

\section{Acknowledgements}

Special thanks must be given to Ali Nihat Gökyiğit Education, Culture, Art and Protection of Wild Life Foundation for funding the project "Biogeographical Distributions of Oaks in Turkey" and to Prof. Dr. M. Tekin Babaç for critical reviewing the manuscript and suggesting improvements.

\section{References}

Abbot L.A., Bisby F.A., Rogers D.J. 1985. Taxonomic analysis in biology. Columbia University Press, New York.

Anagiotos G., Tsakaldimi M., Ganatsas P. 2012. Variation in acorn traits among natural populations of Quercus alnifolia an endangered species in Cyprus. Dendrobiology 68: 3-10.

Bacilieri R., Ducousso A., Petit R.J., Kremer A. 1996. Mating system and asymmetric hybridization in a mixed stand of european oaks. Evolution 50: 900-908.

Bellarosa R., Simeone M.C., Papini A., Schirone B. 2005. Utility of ITS sequence data for phylogenetic reconstruction of Italian Quercus spp. Molecular Phylogenetics and Evolution 34: 355-370.

Blue M.P., Jensen R.J. 1988. Positional and seasonal variation in oak (Quercus: Fagaceae) leaf morphology. American Journal of Botany 75: 939-947.

Borazan A., Babaç M.T. 2003. Morphometric leaf variation in oaks (Quercus) of Bolu, Turkey. Annales Botanici Fennici 40: 233-242.

Bruschi P., Vendramin G.G., Busotti F., Grossoni P. 2000. Morphological and molecular differentiation between Quercus petraea and Quercus pubescens (Fagaceae) in Northern and Central Italy. Annals of Botany 85: 325-333.

Conte L., Cotti C., Cristofolini G. 2007. Molecular evidence for hybrid origin of Quercus crenata Lam. (Fagaceae) from Q. cerris L. and Q. suber L. Plant Biosystems 141: 181-193. 
Davis P.H. 1971. Distribution patterns in Anatolia with particular reference to endemism, In: Davis, P.H., Harper P.C. and Hedge I.C. (eds.), Plant life of South West Asia, Botanical Society of Edinburgh, Edinburgh, pp. 15-27.

Davis P.H., Heywood V.H. 1963. Principles of Angiosperm taxonomy. Oliver and Boy, Edinburgh, London.

Dunn G., Everitt B.S. 1982. An introduction to mathematical taxonomy. Cambridge University Press, Cambridge.

Dupouey J.L., Badeau V. 1993. Morphological variability of oaks (Quercus robur L., Quercus petraea (Matt.) Liebl., Quercus pubescens Willd.) in northeastern France: preliminary results. Annals of Forest Science 50: 35-40.

Ekim T., Güner A. 1986. The Anatolian Diagonal: fact or fiction? Proceedings Royal Society, Edinburgh 89B: 69-77.

Govaerts R., Frodin D.G. 1998. World checklist and bibliography of Fagales (Betulaceae, Corylaceae, Fagaceae, and Ticodendraceae). The Royal Botanic Gardens, Kew.

Hedge I.C., Yaltırık F. 1982. Quercus L.. In: Flora of Turkey and the East Aegean Islands, Davis P.H. (ed.), Edinburgh University Press, Edinburgh, pp. 659-683.

Hokanson S.C., Isebrands J.G., Jensen R.J., Hancock J.F. 1993. Isozyme variation in oaks of the Apostle Islands in Wisconsin: Genetic structure and levels of inbreeding in Quercus rubra and Quercus ellipsoidalis (Fagaceae). American Journal of Botany 80: 1349-1357.

Jensen R.J. 1980. Morphological and phenolic variation in a tree species community of red oaks. Bulletin of the Torrey Botanical Club107 (3): 418 428.

Jensen R.J. 1988. Assessing patterns of morphological variation of Quercus spp. in mixed oak communities. American Midland Naturalist 120: 120-135.

Jensen R.J. 1989. The Quercus falcata Michx. complex in land between the lakes, Kentucky and Tenessee: a study of morphological variation. American Midland Naturalist 121: 245-255.

Jensen R.J., Roberta D., Barbara K.S. 1984. Vegetative characters, population variation the hybrid origin of Quercus ellipsodalis. American Midland Naturalist 111: 364-370.

Kasaplıgil B. 1992. Türkiye'nin geçmişteki ve bugünkü meşe türleri. Orman Bakanlığı, Orman Genel Müdürlüğü yayını, Ankara.

Kremer A., Petit R.J. 1993. Gene diversity in natural populations of oak species. Annals of Forest Science 50: 186-202.

Manos P.S., Zhou Z., Cannon C.H. 2001. Systematics of Fagaceae: phylogenetic tests of reproduc- tive trait evolution. International Journal of Plant Sciences 162: 1361-1379.

Manos P.S., Doyle J.J., Nixon K.C. 1999. Phylogeny, biogeography, and processes of molecular differentiation in Quercus subgenus Quercus (Fagaceae). Molecular Phylogenetics and Evolution 12: 333349.

Menistky Y.L. 2005. Oaks of Asia. Science publisher. U.S.A.

Petit R.J., Pineau E., Demesure B., Bacilieri R., Ducousso A., Kremer A. 1997. Chloroplast DNA footprints of postglacial recolonization by oaks. Proceedings of the National Academy of Sciences USA. 94: 9996-10001.

Samuel R. 1999. Identification of hybrids between $Q$. petraea and $Q$. robur (Fagaceae): results obtained with RAPD markers confirm allozyme studies based on the Got-2 locus. Plant Systematics and Evolution 217: 137-146.

Schwarz O. 1993. Quercus L., In: Flora Europaea. Tutin T.G., Burges N.A., Chater A.O., Edmondson I.R., Heywood V.H., Moore D.M. (eds.), Cambridge University Press, Cambridge, pp. 72-76.

Stace C.A. 1989. Plant taxonomy and biosystematics. Cambridge Univ. Press, Cambridge.

Uslu E., Bakış Y., Babaç M.T. 2011. A study on biogeographical distribution of Turkish oak species and their relations with the Anatolian diagonal. Acta Botanica Hungarica 53: 423-440.

Uslu E., Bakıș Y. 2012. Geographic distribution of Turkish oaks. Dendrobiology 67: 41-48.

Yaltırık F. 1984. Türkiye meşeleri teşhis kılavuzu. Yenilik basımevi, İstanbul.

Zielinski J., Petrova A., Tomaszewski D. 2006. Quercus trojana subsp. Yaltirikii (Fagaceae), a new subspecies from southern Turkey. Willdenowia 36: 845-849.

Zohary M. 1973. Geobotanical foundations of the Middle East. Gustav Fischer Verlag, Stuttgart,und Swets and Zeitlinger, Amsterdam.

Zúñiga E.Á., Sánchez-González A., Sánchez D.G. 2009. Análisis de la variación morphológica foliar en Quercus laeta Liebm. en el Praque Nacional Los Mármoles, Hidalgo, Mexico. Revista Chapingo Serie Ciencias Foretales y del Ambiente 14(2): 87-93. 


\section{Appendix 1}

Geographical information of OTUs belongs to Section Cerris. Bold characters indicate population numbers, and the others are province name, GPS coordinates, and altitude, respectively

Q. brantii - BRN156: Tunceli, $39^{\circ} 11.540 \mathrm{~N}-39^{\circ}$ 42.114 E, 1025 m. BRN158: Elazığ, $39^{\circ} 03.650 \mathrm{~N}$ $38^{\circ} 30.024$ E, 1135 m. BRN172: Hatay, $36^{\circ} 28.514$ $\mathrm{N}-036^{\circ} 16.735$ E, $500 \mathrm{~m}$. BRN078: Gaziantep, $37^{\circ} 22.709 \mathrm{~N}-037^{\circ} 33.114 \mathrm{E}, 780 \mathrm{~m}$. BRN284: Adiyaman, $37^{\circ} 94.765 \mathrm{~N}-038^{\circ} 75.966 \mathrm{~N}, 1410 \mathrm{~m}$. BRN283: Adıyaman, $37^{\circ} 91.929 \mathrm{~N}-038^{\circ} 75.966$ E, 870 m. BRN287: Elazığ, $38^{\circ} 22.052 \mathrm{~N}-039^{\circ}$ $10.101 \mathrm{~N}, 1440 \mathrm{~m}$. BRN286: Elazığ, $38^{\circ} 27.634 \mathrm{~N}-$ $038^{\circ} 53.891 \mathrm{E}, 1020 \mathrm{~m}$. Q. cerris var. cerris - CRR018: Malatya, $38^{\circ} 13.624 \mathrm{~N}-038^{\circ} 51.004 \mathrm{E}, 1045 \mathrm{~m}$. CRR260: Muğla, $37^{\circ} 08.141 \mathrm{~N}-028^{\circ} 18.215,650 \mathrm{~m}$. CRR266: Çanakkale, $39^{\circ} 34.484 \mathrm{~N}-026^{\circ} 30.340 \mathrm{E}$, 340 m. CRR269: Bolu, $40^{\circ} 31.455 \mathrm{~N}-031^{\circ} 04.985$ E, 640 m. CRR271: Düzce, $40^{\circ} 49.916 \mathrm{~N}-030^{\circ}$ 53.400 E, 260 m. CRR074: Tokat, $40^{\circ} 12.481 \mathrm{~N}-$ 036 30.590 E, 1140 m. CRR076: Kahramanmaraş, $38^{\circ} 07.976 \mathrm{~N}-036^{\circ} 49.134 \mathrm{E}, 1125 \mathrm{~m}$. CRR097: Bilecik, $39^{\circ} 58.940 \mathrm{~N}-030^{\circ} 07.890 \mathrm{E}, 890 \mathrm{~m}$. CRR101: Kütahya, $39^{\circ} 12.910 \mathrm{~N}-030^{\circ} 07.410 \mathrm{E}, 1110 \mathrm{~m}$. CRR121: Bursa, $39^{\circ} 55.761 \mathrm{~N}-028^{\circ} 32.657 \mathrm{E}, 120$ m. Q. ithaburensis subsp. macrolepis - ITH104: Uşak, $38^{\circ} 55.761 \mathrm{~N}-029^{\circ} 40.485 \mathrm{E}, 760 \mathrm{~m}$. ITH123: Bal1- kesir, $39^{\circ} 25.467 \mathrm{~N}-026^{\circ} 55.435 \mathrm{E}, 140 \mathrm{~m}$. ITH122: Balıkesir, $39^{\circ} 30.036 \mathrm{~N}-026^{\circ} 55.990 \mathrm{E}, 10 \mathrm{~m}$. ITH253: İzmir, $38^{\circ} 57.266 \mathrm{~N}-026^{\circ} 48.313 \mathrm{E}, 130 \mathrm{~m}$. ITH259: Muğla, $37^{\circ} 80.059 \mathrm{~N}-028^{\circ} 10.388 \mathrm{E}, 580$ m. ITH218: Çanakkale, $39^{\circ} 54.438 \mathrm{~N}-026^{\circ} 10.741$ E, 30 m. ITH198: İzmir, $39^{\circ} 10.503 \mathrm{~N}-026^{\circ} 51.387$ E, $120 \mathrm{~m}$. ITH130: Çanakkale, $39^{\circ} 49.153 \mathrm{~N}-026^{\circ}$ 51.388 E, $121 \mathrm{~m}$. ITH127: Antalya, $36^{\circ} 25.862 \mathrm{~N}-$ $029^{\circ} 55.469$ E, $500 \mathrm{~m}$. Q. libani - LIB152: Tunceli, 39 $33.300 \mathrm{~N} 39^{\circ} 53.403 \mathrm{E}, 1500 \mathrm{~m}$. LIB155: Tunceli, 39॰ $14.059 \mathrm{~N}-039^{\circ} 45.040$ E, 1030 m. LIB159: Erzincan, $39^{\circ} 12.552 \mathrm{~N} 38^{\circ} 35.229 \mathrm{E}, 930 \mathrm{~m}$. LIB087: Bingöl, $38^{\circ} 58.110 \mathrm{~N}-041^{\circ} 05.685 \mathrm{E}, 1490 \mathrm{~m}$. LIB285: Adiyaman, $37^{\circ} 56.833 \mathrm{~N}-038^{\circ} 43.149 \mathrm{E}, 1670 \mathrm{~m}$. LIB283: Adiyaman, $37^{\circ} 56.139 \mathrm{~N}-038^{\circ} 48.180 \mathrm{E}$, 890 m. LIB288: Elazığ, $38^{\circ} 21.280 \mathrm{~N}-039^{\circ} 09.002 \mathrm{E}$, 1440 m. LIB082: Bitlis, $38^{\circ} 19.529 \mathrm{~N}-042^{\circ} 06.577$ E, 1640 m. Q. trojana subsp. trojana - TRJ267: Çanakkale, $40^{\circ} 11.642 \mathrm{~N}-026^{\circ} 035.124 \mathrm{E}, 225 \mathrm{~m}$. TRJ265: Uşak, $38^{\circ} 34.259 \mathrm{~N}-029^{\circ} 36.303 \mathrm{E}, 825 \mathrm{~m}$. TRJ163: Karaman, $37^{\circ} 09.275 \mathrm{~N}-033^{\circ} 25.659 \mathrm{E}, 1100 \mathrm{~m}$. TRJ185: Kütahya, $39^{\circ} 21.732 \mathrm{~N}-030^{\circ} 02.756 \mathrm{E}$, 970 m. TRJ033: Konya, $37^{\circ} 38.985 \mathrm{~N}-031^{\circ} 26.805$ E, 1180 m. TRJ105: Kütahya, $39^{\circ} 17.287 \mathrm{~N}-029^{\circ}$ $13.584 \mathrm{E}, 760 \mathrm{~m}$. TRJ031: Isparta, $37^{\circ} 44.842 \mathrm{~N}-$ $030^{\circ} 49.269$ E, $1300 \mathrm{~m}$. TRJ027: Muğla, $36^{\circ} 25.862$ $\mathrm{N}-029^{\circ} 55.469$ E, $500 \mathrm{~m}$. TRJ035: Konya, $37^{\circ}$ $00.682 \mathrm{~N}-032^{\circ} 28.312 \mathrm{E}, 1470 \mathrm{~m}$. 